\title{
34. FISSION TRACK CHRONOLOGY AND URANIUM CONTENT OF BASALTS FROM DSDP LEG 34
}

\author{
W.S. Mitchell and F. Aumento, Department of Geology, Dalhousie University, Halifax, Nova Scotia, Canada
}

\begin{abstract}
Natural basaltic glasses from Leg 34 Holes 319A and 320B on the Nazca plate have been dated using fission track techniques. Fission track ages of $17.8 \pm 3.0$ m.y. for Hole $319 \mathrm{~A}$ and $25.2 \pm 3.4 \mathrm{~m} . \mathrm{y}$. for Hole $320 \mathrm{~B}$ concur with the ages of sediments directly overlying the basalts at these sites. ${ }^{40} \mathrm{Ar} /{ }^{39} \mathrm{Ar}$ dating techniques have also been applied to material from Hole 319A (Reynolds, this volume). Although the average age $\left(\sim 19\right.$ m.y.) obtained using the ${ }^{40} \mathrm{Ar} /{ }^{39} \mathrm{Ar}$ method is slightly greater than the fission track age, the agreement in ages obtained from two totally different techniques is well within the limits of error imposed on either method. Uranium content of the glasses used for dating purposes is very low and may reflect original, unaltered uranium values.

Fission track techniques were also utilized to determine amounts of uranium present in various basalt samples from Holes 319A, 320B, and Site 321. Uranium concentrations, which are very low in fresh basalts, increase significantly in basalts which show even the slightest signs of alteration.
\end{abstract}

\section{EXPERIMENTAL PROCEDURE}

Glasses from Leg 34, Holes 319A and 320B were dated in essentially the same way as described by Fleischer and Price (1964). A piece of glass from each site was sliced along its longest dimension to expose two fresh glassy surfaces. One part of the sample was retained for counting spontaneous tracks resulting from the decay of ${ }^{238} \mathrm{U}$, while the other part was irradiated in a highly thermalized neutron flux to induce fission of ${ }^{235} \mathrm{U}$ in the sample. The neutron dose for each sample was monitored separately by standard glasses of known uranium content. The standard glass, the irradiated, and nonirradiated portions of the same natural glass sample were all placed together in the same mount. This ensured that all samples were polished identically, and even more important, were etched under identical conditions, a critical factor in fission track counting on an abosolute basis for the purpose of dating (Reimer, 1974).

Only the fresh, well-polished surfaces of the glasses were used for counting purposes. Densities of spontaneous tracks in the natural unirradiated glass from both sites were so low that the mounts had to be reground, polished, and etched several times to increase the area for counting spontaneous tracks.

Error limits imposed on the ages are the cumulative total of errors resulting from the counting statistics in the natural, irradiated, and standard glasses.

Methods of determining uranium concentrations in homogenized whole rock samples have been described by Fisher (1970). Again, in this work, standard flux monitor glasses of known uranium content were used to calibrate each sample. The absolute accuracy of results obtained by this method is approximately $10 \%$ (Fisher,
1972), and since only fission of ${ }^{235} \mathrm{U}$ takes place, the total amount of uranium present is calculated assuming a constant ${ }^{235} \mathrm{U} /{ }^{238} \mathrm{U}$ ratio.

Microscopic examination of thin rock slices from these Leg 34 samples proved useful in distinguishing fresh and altered basalts. The uranium concentrations in the basalts could thus be compared to their state of alteration as established by microscopic examination.

\section{RESULTS}

Results of the fission track dating of Leg 34 basaltic glasses are presented in Table 1. The calculated age of the glass from Hole $319 \mathrm{~A}$ is $17.8 \pm 3.0 \mathrm{~m} . \mathrm{y}$., a result which fits in well with the early Miocene age (approximately $19 \mathrm{~m} . \mathrm{y}$.) of the nanno ooze sediment directly overlying the basalt. Glass from Hole 320B was found to be $25.2 \pm 3.4 \mathrm{~m} . \mathrm{y}$. old, again in good agreement with the age of the sediment overlying the basalt which in this area is a late Oligocene foram nanno ooze (25-30 m.y.). ${ }^{40} \mathrm{Ar} /{ }^{39} \mathrm{Ar}$ dating techniques on basalts from Hole 319A (Reynolds, this volume) give an age of approximately 19 m.y. which, although somewhat higher than the fission track age, is still within the limits of error imposed on either dating technique. The successful application of fission track dating methods to glasses obtained from Leg 34 of the JOIDES project is attributed to the unusually fresh nature of the basalts at both sites. Low ambient temperatures, low compaction loads, and the lack of any strong hydrothermal alteration are believed to have contributed to the preservation of the spontaneous tracks in the Leg 34 glass samples.

The uranium contents of the glasses and of whole rock powders from the different drill sites are listed in Table 2. The glass samples from Holes 319A and 320B contain equally low uranium concentrations (29-31 
TABLE 1

Fission Track Ages of Glass From Holes 319A and 320B

\begin{tabular}{lccccc}
\hline \multicolumn{1}{c}{ Sample } & $\begin{array}{c}\text { Spontaneous } \\
\text { Track Density } \\
(\text { tracks/cm }\end{array}$ & $\begin{array}{c}\text { Induced } \\
\text { Track Density } \\
\left(\text { tracks } / \mathrm{cm}^{2}\right)\end{array}$ & $\begin{array}{c}\text { Neutron Flux } \\
(\mathrm{nvt})\end{array}$ & $\begin{array}{c}\text { Age } \\
(\mathrm{m} . \mathrm{y} .)\end{array}$ & Foram Zone \\
\hline $\begin{array}{l}\text { Hole 319A } \\
\begin{array}{l}\text { Glass hole } \\
\text { cuttings }\end{array}\end{array}$ & $81.73 \pm 16.7 \%$ & $4685.09 \pm 3.12 \%$ & $1.665 \times 10^{16} \pm 2.93 \%$ & $17.78 \pm 3.05$ & N8 (early Miocene) \\
$\begin{array}{l}\text { Hole 320B } \\
\text { 3-1, 102-105 cm }\end{array}$ & $123.57 \pm 12.6 \%$ & $4635.96 \pm 3.21 \%$ & $1.545 \times 10^{16} \pm 3.07 \%$ & $25.21 \pm 3.37$ & N2 (late Oligocene) \\
\hline
\end{tabular}

ppb), which are significantly less than even the lowest uranium concentrations determined in the basalts. The values of uranium in the glass may therefore reflect the original unaltered uranium content of the magma from which they are derived.

All basalt samples from Hole 319A appear uniformly fresh on microscopic examination and contain amounts of uranium in the range $60-120 \mathrm{ppb}$, with an average value of $87 \mathrm{ppb}$. This average is only slightly higher than an average value of $75 \mathrm{ppb}$ uranium, considered the basic uranium content of East Pacific tholeiitic basalts (Fisher, 1971). However, it seems reasonable to assume that the considerably lower uranium concentrations (29$31 \mathrm{ppb}$ ) in the quenched basaltic glasses represent the basic uranium content of the parent magma, and we can only conclude that even though the basalts of Hole 319A appear extremely fresh, they have undergone some uranium contamination from seawater.

The only basalt sample from Hole 320B contains significantly more uranium than any of the basalts in Hole 319A. Since this basalt is visibly altered on a microscopic scale, the high uranium value is attributed to halmyrolysis (Aumento, 1971). It is interesting to note, however, that the glass from Hole 320B contains virtually the same low amount of uranium as the glass from Hole 319A.

Concentrations of uranium in basalts from Site 321 are variable and are, on the average, much higher than

TABLE 2

Uranium Concentrations in Whole Rock Basalt Samples and Natural Glass

\begin{tabular}{llc}
\hline \multicolumn{1}{c}{ Hole } & \multicolumn{1}{c}{$\begin{array}{c}\text { Sample } \\
\text { (Interval in cm) }\end{array}$} & $\begin{array}{c}\text { U Concen- } \\
\text { tration (ppb) }\end{array}$ \\
\hline 319A (glass) & Glass hole cuttings & 29 \\
319A & $1-1,39-42$ & 110 \\
319A & $2-1,146-149$ & 120 \\
319A & $3-5,81-84$ & 90 \\
319A & $4-1,141-144$ & 60 \\
319A & $5-1,72-75$ & 70 \\
319A & $6-1,142-145$ & 90 \\
319A & $7-1,116-119$ & 70 \\
320B (glass) & $3-1,102-105$ & 31 \\
320B & $3-1,117-120$ & 640 \\
321 & $13-4,142-145$ & $1.47^{\mathrm{a}}$ \\
321 & $14-1,58-61$ & 600 \\
321 & $14-2,117-120$ & 100 \\
321 & $14-3,44-47$ & $1.33^{\mathrm{a}}$ \\
321 & $14-4,45-48$ & 100 \\
\hline
\end{tabular}

${ }^{\mathrm{a}} \mathrm{ppm}$. concentrations found in Hole 319A. Thin sections of the three samples from Site 321 with the highest uranium content exhibit small irregular patches of alteration in the matrix material, although the larger crystallites of plagioclase and clinopyroxene appear as fresh as the same minerals in the Hole 319A samples. The core log also indicates that these three samples are close to joint surfaces which may have acted as channelways for percolating solutions. Again these high uranium values must be attributed to halmyrolysis.

No visible microscopic alteration could be seen in the thin sections of the remaining basalts from Site 321 which both contain $100 \mathrm{ppb}$ uranium. Since no glass from this hole was analyzed, we do not know what the original uranium content of the basalts at this site may have been. However, it seems probable that the 100-ppb value does not represent the original uranium content of the basalts at Site 321 since the rocks penetrated at this site are the oldest of any of the Leg 34 Nazca plate sites and have, therefore, been subjected to a longer period of interaction with seawater.

\section{DISCUSSION AND CONCLUSIONS}

The successful application of fission track dating techniques to natural glass recovered from Leg 34 of the JOIDES project indicates that the shock-induced annealing of tracks during the drilling process is not a problem, at least in the fresh basalts penetrated in two of the Nazca plate drill sites. The feasibility of applying fission track dating techniques to oceanic rocks seems, therefore, to depend largely on the degree of halmyrolysis, the ambient temperatures, and the pressures to which the rocks are subjected. The unusually fresh nature of the material recovered undoubtedly contributed to the successful age determination of the glasses from Holes 319A and 320B.

If the low uranium content of the quenched basaltic glass does reflect the basic concentration of the element in the parent magma, it would appear that even the apparently fresh basalts from Hole $319 \mathrm{~A}$, which contain on the average more uranium than the glasses, have undergone some uranium enrichment. Progressively higher uranium concentrations in basalts from Hole 320B and Site 321 can be correlated with the observed intensity of alteration of the rocks.

It is interesting to note that average values of uranium in basalts from Holes 319A and 320B and Site 321 increase with age, presumably reflecting the period of time during which the rocks were subject to halmyrolysis. 
This suggests that the possiblity of making quick, though probably crude age estimates of oceanic crust on this basis should be investigated.

\section{REFERENCES}

Aumento, F., 1971. Uranium content of mid-oceanic basalts: Earth Planet. Sci. Lett., v. 11, p. 90-94.
Fisher, D.E., 1970. Homogenized fission track determination of uranium in whole rock geological samples: Anal. Chem., v. 42 , p. $414-416$.

1971. Incoporation of Ar in East Pacific Basalts: Earth Planet. Sci. Lett., v. 12, p. 321-324.

, 1972. U/He ages as indicators of excess argon in deep sea basalts: Earth Planet. Sci. Lett., v. 14, p. 255-258.

Fleischer, R.L. and Price, P.B., 1964. Glass dating by fission fragment tracks: J. Geophys. Res., v. 69, p. 331-339.

Reimer, G.M., 1974. Effect of progressive etching on fission track ages, Am. Nuc. Soc. Trans., v. 18, p. 87. 